\title{
THE TRANSLATION OF ELLIPSIS AND EVENT REFERENCE IN JK ROWLING'S HARRY POTTER AND THE GOBLET OF FIRE
}

By:

\section{Adi Loka Sujono}

\begin{abstract}
The study aims to investigate the translation of ellipsis and event reference in $J K$ Rowling's' Harry Potter and the Goblet of Fire. In this present study, a qualitative content analysis method was employed. In translating the ellipsis and event reference, semantic and syntactic referents should be taken into account. Concerning with reference to eventualities, three forms of referents namely verb phrase ellipsis, so anaphora and pronominal event reference are analysed. Some adjustments such as literal translation, explicitation, omission, and the like are made.
\end{abstract}

Key words:

\section{INTRODUCTION}

The term 'translation' means the reproduction in the receptor language of the closest natural equivalent of the receptor message, first in terms of meaning, and secondly in terms of style (Nida: 1982). The definition implies that in translation, the most important thing to remember is to find out the nearest equivalent between the ST (Source Text) and the TT (Translation Text) dealing with the meaning, content or message, when the TT is written as if it is not a translation. Besides, styles should also be taken into account. In short, meaning should be given priority since the main purpose of translation is to convey the content of the source text into the content of the target text with appropriate style.

In literary translation, the terms 'meaning' and 'style' play a pivotal role. In this case, translators are required to be able to produce translation which is as beautiful and forceful as the original with a good accuracy. Literary translations, therefore, can be said to be the works of the literary translators....their imaginative, intellectual an intuitive writings should not be lost to the abstraction which is often described as 'translation' (Bassnet: 2002). Literary translation is not only replicating a text in another verbal style of signs but also an ordered sub-system of signs within a given language in another corresponds ordered sub-system within a related language. In other words, translation is not the act of transposing signs, but a revitalization of the original in another verbal order and temporal space, since when the translation has been finished, the original work is still in the original position (Ibid, 2006: 8687).

Therefore, in the translation of prose, including novels, in order to be able to produce a good translation, there are six general rules the translator should obey (Belloc in Bassnet, 
2002) namely : (1) the translator does not translate word by word or sentence by sentence, but should consider the work as an integral unit; (2) the translator must render idiom by idiom; (3) the translator must render intention by intention; where intention mans the weight of a given expression may have in a particular context in the SL that should be disproportionate if the translated literally into the TL; 4) the translator should be cautious about les faux miss, those words or structures that may appear to correspond both in SL and TL but actually do not; (5) The translator is advised to 'transmute boldly' where the essence of translating is 'the resurrection of an alien thing in a native body'; and (6)the translator should never embellish. In this matter, Belloc really stresses the need for the translator to consider the prose text as structures while taking into account the stylistic and syntactic forms.

If the six general rules are adopted by literary translators, high-quality translation is produced. In general, a high-quality translation includes accuracy, clarity and naturalness (Barnwell: 1984). Accuracy means that the content of the ST is properly rendered into the TT. Clarity implies that although there are some ways to express messages or ideas, but there is the best way used to express them so that the translation is easily understood by the readers. Naturalness is that the message in the ST is conveyed naturally ad properly so that the translation will not be felt as translation.

In this present study, the object of the study is JK Rowling's Harry Potter and the Goblet of Fire. This novel is chosen due to the fact that it is one of JK Rowling's famous works. It has been translated into many languages, including Indonesian, and even it has been filmed. The study would be focused on the translation of ellipsis and event reference existing in this novel. Ellipsis and event references are chosen because from the best knowledge of the writer, the ellipsis and event reference are difficult to translate since it involves deep interpretation.

In natural languages, to refer to things in a discourse, a wide variety of linguistic devices that may be used by speakers are available (Kehler and Word: 2006). The use of the reference of things or of referring expressions is constrained by three sources of information namely the speakers' belief about the knowledge of the hearer, the state of the hearer's discourse model (representing the entities and eventualities introduced) and about the situational context of the discourse (including entities and eventualities within the interlocutors' perceptional spheres.

In analyzing the constraints, in this study, three properties will be distinguished. The first distinction is based on the level of representation, namely whether a referential expression needs the existence of an antecedent of a syntactic form or just a semantic 
referent. Hankamer and Sag (1976) in Kehler and Ward (2006) proposed deep and surface anaphora, where surface anaphora are syntactically controlled ,namely regaining a linguistic antecedent of a particular syntactic form, and deep anaphora are pragmatically controlled, where the referent is induced semantically without any linguistic introduction. For example in the sentence A peace agreement in the Middle East needs to e negotiated. (a) An agreement

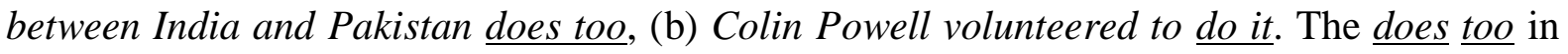
(a) is surface anaphora, while the does too in (b) is deep anaphora.

The second distinction deals with semantic referents, whether they are old or new (speaker's or hearer's beliefs). For instance, in I bought a book at e bookstore today and I bought The Handbook of Pragmatics, the phrases a book and The handbook of Pragmatics represent discourse-new referents. But in the sentence I bought a book at the bookstore today. The book had been marked down to 99 cents, the phrase The book is discourse-old since it was previously introduced.

The third distinction in reference in discourse is salience. According to Price (1981a), Ariels (1990), Gundel et all (1993) and Lambrecht (1994) in Kehler and Ward (2006), salience deals with old-discourse referents. Salience serves as an important factor in explaining the cognitive status of referents. Gundel et all proposed a givens hierarchy containing 6 categories distinguishing levels of salience that determine the forms of definite reference (but ere just 4used); namely (1) in focus-referent (pronouns); (2) activated-referents (demonstratives: that, this, this $N$ ); 3)familiar referents (that $N$ ) and uniquely identifiable (a $N)$.

So far referents have been classified in terms of 3 properties: the level at which they are represented in the discourse model (syntax or semantics; the case of semantic referents (old or new information status) and hearer(-old) referents (their relative levels, salience).

Now, concerning with reference to eventualities, there are four forms: gapping, verb phrase ellipsis, so anaphora and pronominal event reference. Gapping construction. Hankamer and Sag (1976) in Kehler and Ward (2006) categorizes this gapping construction as a form of surface anaphora. For example in George won the electoral vote, and $\mathrm{Al}$, the popular vote. The sentence consists of two parts: the first part is called the source clause (antecedent clause) and the second is target clause (containing elliptical or referential form).

Levin and Prince (1986) differentiated between symmetric and asymmetric readings which may result in ambiguity for instance, in sentence Sue became upset and Nan became downright angry and Sue became upset and Nan --- downright angry. In the first sentence (symmetric interpretation), it is shown that Sue and Nan both expressed independent 
emotions (from the same provocateurs), whereas in the second sentence (asymmetric interpretation) it is shown that Nan became angry because of Sue's becoming upset.

Verb phrase ellipsis construction. Hankamer and Sag (1976) categorized verb phrase ellipsis as a form of surface anaphora, where it is only licensed if an antecedent of an appropriate syntactic form is available. In the sentence George claimed he won the election, and Al did too. The pronoun in the source clause may produce two possible interpretations for the target clause: either Al claimed that George won the election or Al claimed that Al won the election. However there are some examples showing that verb phrase ellipsis is felicitous although appropriate syntactic antecedent is available. See the following example: George expected Al to win the election vote when he didn't. In this sentence the ellipsis he didn't refers to expect Al to win the election.

So anaphora construction. The particular form of anaphoric so in this case can appear in preverbal and post verbal positions as shown in the following:

1. “... and with complete premeditation resolved that this Imperial Majesty Haile Selassie should be strangled because he was head of the feudal system." He was so strangled on Aug.26, 1975 in his bed most cruelly.

2. Section 1 provides the examples to be derived by Gapping, and a formulation of Gapping able of doing so. . The Ellipsis doing so represents deriving the examples.

From the two examples, the anaphor so and the form do so are treated as surface anaphors.

However, there are also examples showing that verb phrase ellipsis can be used although appropriate syntactic antecedent is unavailable. For example: George expected Al to win the election even when he didn't. In this sentence, the ellipsis he didn't refers to expect Alto win the election.

However, the ellipsis does so can be used although the voice between the source and the target clauses is mismatched. For instance in the sentence Section 1 provides the examples to be derived by Gapping, and a formulation of Gapping capable of doing so. In the example, no active voice syntactic representation for the verb phrase "deriving the examples" is unavailable in the source clause therefore the doing so representing deriving the example.

Moreover, ellipsis do so can be used when its efferent is evoked from a nominalization; for example: The defection of the seven moderate, who knew they were incurring the worth of colleagues in doing so, signaled that ..... In the example, the doing so refers to deflecting which is for the Noun the deflection.

Pronominal event reference construction. Pronominal event reference here is represented by do it, do this and do that, as presented in the following examples: 
1. As the said about Ginger Rogers: "She did everything Fred Astaire did, and she did it backwards and in high heels."

2. Writing is a passion, and a film about the genesis of a writer should delve into the mind and heart of its subject; That "Becoming Colette" tries to do this is irrelevant, because it doesn't succeed.

3. So off he goes, writing in his diary the whole 3 day trip and complaining about the food and the runs I suppose, like all English people do when they go abroad, but he writes very well considering he's riding on a bumpy train, I mean he even smears his ink "once” (I'm bitter, I can't do that with 'my' fountain pens.).

The verb $d o$ in these construction function as the main verb, instead of an auxiliary, although this verb is transitive. And these forms are full verb phrases where nothing is elided. In the expressions the anaphoric properties are taken from the pronouns occupying the object position constrained by the transitive main verb $d o$ in order to specify an event. The expressions clearly are forms of deep anaphora which do not need antecedent.

Moreover, the word that can be used to refer to different type of referents as shown in the example:

1. That's my brother-in-law

2. That is a lie.

3. That's false

4. That's a funny way to describe the situation.

5. When did that happen.

The referents in each case are (1) an entity; (1) a speech act; (3) a proposition; () an expressed description and (5) an event. Therefore, although the referent that may be constrained for its accessibility in the discourse context the type of referent in fact is relatively unconstrained.

\section{METHODOLOGY}

The study is conducted using a qualitative content analysis method, and attempts to analyze the translation of Verb Phase Ellipsis, So Anaphora and Pronominal Event reference in the JK Rowling's Harry Potter and the Goblet of Fire in order to know whether the translator may rightly identify the proper referents.

In order to get the data, the researcher read the source text many times, identified the ellipsis and reference, and then found out their translation in the Indonesian version. Then they were classified into the forms and then shifts or deviations were explained. 


\section{III.FINDINGS AND DISCUSSION}

As stated above, people use their natural languages in a wide variety of linguistic devices in order to refer to things. But, they do not use them in a random way, but they might depend their choices on their beliefs whether their hearers have prior knowledge of the referent, they have been mentioned before or they are situated in the surroundings of the participant (Kehler and Ward, 2006).

The followings will be presented the findings and also the discussions in terms of three, instead of four, options in terms of verb phrase ellipsis, so anaphora, and pronominal event reference.

\section{Verb Phrase Ellipsis}

Hankamer and Sag (1976) proposed a distinction between deep and surface anaphora. The first is syntactically controlled, meaning that a linguistic antecedent of a particular syntactic form is required. Whereas the second is pragmatically controlled where such an antecedent is not needed, and the referent is evoked situationally. These can be seen in the following examples:

(Example 1)

The Hanged Man, the village pub, did a roaring trade that night; the whole village seemed to have turned out to discuss the murders. They were rewarded for leaving their firesides when the Riddles' cook arrived dramatically in their midst and announced to the suddenly silent pub that a man called Frank Bryce had just been arrested.

"Frank!" cried several people. "Never!" (p.1)

The utterance "Never" on the example does not refer to a linguistics of a particular syntactic form, but it depends on the situation previously described, where this is called deep anaphora. According to Kehler $(200 \mathrm{a}, 2002)$ this may be explained from the interaction between properties of verb phrase ellipsis and those of the inference processes underlying the establishment of coherence in discourse. The example shows that the people said "Never" since they wandered that Frank Bryce was arrested for the murder.

The Hanged Man, rumah minum di desa itu, laris bukan buatan malam itu. Seluruh desa tampaknya keluar untuk mendiskusikan pembunuhan ini. Imbalan karena telah meninggalkan perapian, mereka peroleh ketika juru masak keluarga Riddle tiba secara dramatis di tengah mereka dan mengumumkan kepada hadirin di rumah minum yang mendadak sunyi bahwa seorang pria bernama Frank Bryce baru saja ditangkap.

"Frank!" teriak beberapa orang. "Mana mungkin!" (p.1) 
It seems that the translator properly rendered the utterance "Never" into "Mana mungkin" instead of "Tidak pernah". This shows that the translator really realized that the people are surprised with the arrest of Frank.

Compare the referent above with the utterance presented in Example 2.

(Example2)

"As far as I'm concerned, he killed them, and I don't care what the police say," said Dot in the Hanged Man. "And if he had any decency, he'd leave here, knowing as how we knows he did it."(3)

"Menurutku dia membunuh mereka, dan aku tak peduli apa yang dikatakan polisi," kata Dot di The Hanged Man. "Dan kalau dia punya harga diri, mestinya dia meninggalkan desa ini, karena tahu kita tahu dia pelakunya."(2)

The literal rendering of the verb phrase ellipsis he did it is dia melakukan pembunuhan itu. But for the sake of naturalness as suggested by Nida and Taber(1984) the translation is dia pelakunya where this translation is appropriate due to the fact that the verb phrase ellipsis is in an oral context. The following example shows the verb phrase ellipsis with the type of surface anaphora. It is because the ellipsis is made based on the existing appropriate syntactic antecedent, kill Bertha.

In the example 3 below, the referent is clearly represented by the antecedent. (Example 3)

"Wormtail, Wormtail," said the cold voice silkily, "why would I kill you? I killed Bertha because I had to. (7)

"Wormtail, Wormtail," kata suara dingin itu licin, "buat apa aku membunuhmu? Aku membunuh Bertha karena terpaksa. (5)

As in the above cases, the translator makes a little shift in meaning from the translation I had to aku harus (membunuhnya) into terpaksa (membunuhnya). In this case terpaksa means that the doer actually did not want to kill him, but it was the condition that he did the killing. If the translator rendered had to into harus membunuhnya, it implies that there was someone else who asked him to kill the person.

In example 4, the verb phrase ellipsis is syntactically controlled or called surface anaphora.

\section{(Example 4)}

I don't know what's going to happen to them, I really don't. No ambition, unless you count making as much trouble as they possibly can..." (36)

Aku tak tahu mau jadi apa mereka nanti, benar-benar tak tahu. Tak punya ambisi, kecuali kalau membuat sebanyak mungkin keributan dianggap ambisi..."

The verb phrase I really don't refers to the antecedent of I don't know what's going to happen to them. But the speaker merely did not continue his utterance since he believed that the hearer had known the content of the utterance or hearer-old information (Prince,1992). 
The translation of I really don't is benar-benar tidak tahu with the omission of I because there is difference in system where English is subject prominent language.

Surface anaphora is also shown with the ellipsis of that + be bellow: (Example 5)

"Krum's one decent player, Ireland has got seven," said Charlie shortly. "I wish England had got through. That was embarrassing, that was."(39)

"Krum cuma satu pemain hebat, Irlandia punya tujuh," kata Charlie singkat.

"Sayang sekali Inggris tidak berhasil lolos. Memalukan benar". 29)

The that was as the target clause is omitted in the translation. This happens because the translator might think that the omission will not reduce the meaning or the message.

The following verb phrase ellipsis has a similar same form from that of Example 4, but it is semantically-controlled or deep anaphora.

\section{(Example 6)}

"Wow - hope it does this time!" said Harry enthusiastically.

"Well, I certainly don't," said Percy sanctimoniously. "I shudder to think what the state of my in-tray would be if I was away from work for five days." (40)

"Wow-mudah-mudahan kali ini juga!" kata Harry antusias.

"Kuharap tidak," kata Percy sok rajin. "Aku bergidik memikirkan tumpukan surat-masukku kalau aku meninggalkan kantor selama lima hari." (29)

The translator translates I certainly don't into Kuharap tidak. It is a literal translation. The ellipsis is literally translated because the translator might think that the reader has known the implicit information from the antecedent "Wow-hope it does the time"

The negative interrogative form is shown in the verb phrase ellipsis, referring to the previous utterance as shown in Example 9.

\section{(Example 8)}

"Aye," he said thoughtfully. "People from all over. Loads of foreigners. And not just foreigners. Weirdos, you know? There's a bloke walking 'round in a kilt and a poncho."

"Shouldn't he?" said Mr. Weasley anxiously (p.48)

"Ya," katanya sambil menerawang. "Orang dari segala tempat. Banyak sekali orang asing. Dan bukan cuma orang asing. Orang-orang aneh, Anda tahu? Ada yang berkeliaran memakai kilt dan ponco."

"Apa itu aneh?" tanya Mr Weasley ingin tahu. (p.36)

The verb phrase ellipsis is of the type of deep anaphora, referring to the previous utterance There's a bloke walking 'round in a kilt and a poncho. The verb phrase ellipsis "Shouldn't he" means that is it amazing if there is a person wandering while wearing kilt and poncho. That's is why that the translation of the verb phrase is "Apa itu aneh?" (from Apa itu aneh kalau ada rang yang berkeliaran memakai kilt and poncho).

Dealing with deep anaphora, the form negative answer" is employed as shown in Example 9. 
"I pull down about a hundred sacks of Galleons a year!" one of them shouted. "I'm a dragon killer for the Committee for the Disposal of Dangerous Creatures."

"No, you're not!" yelled his friend. "You're a dishwasher at the Leaky Cauldron... but I'm a vampire hunter, I've killed about ninety so far -" (p.78)

"Aku pembunuh naga untuk Komite Pemunahan Satwa Berbahaya."

"Bohong!" teriak temannya. "Kau pencuci piring di Leaky Cauldron... tapi aku pemburu vampir, sejauh ini aku sudah membunuh sembilan puluh..." (p.57)

The verb phrase ellipsis "No. you're not" actually is from the complete utterance "Now, you're not the dragon killer for the Committee for the Disposal of Dangerous", so that ellipsis is categorized into a surface anaphora. And the translator does not translate "No, you are not" into Bukan, anda bukan" but "Bohong”, in order to give an emphasis.

The last case in Verb Phrase Ellipsis is the form Subject + will + too, as shown in Example 10.

(Example 10)

Ron and Hermione looked curiously at Harry. With a meaningful look at both of them he said, "All right if I go and dump my stuff in your room, Ron?"

"Yeah... think I will too," said Ron at once. "Hermione?" (93)

Ron dan Hermione memandang Harry ingin tahu.

Dengan pandangan penuh arti kepada mereka, Harry berkata, "Boleh aku taruh barang-barang di kamarmu, Ron?"

"Yeah... kurasa aku juga mau menaruh barang-barangku," kata Ron segera tanggap (68)

The type of this ellipsis is surface anaphora, where the antecedent is derived from the the syntactical form of the previous sentence. The verb phrase ellipsis "I will too" means $I$ will go and dump my stuff in your too. In the translation, the translator gives a full sentence namely Yeah... kurasa aku juga mau menaruh barang-barangku instead of "Saya juga mau" which is an unnatural utterance in bahasa Indonesia.

\section{So Anaphora}

This do so construction, in terms of the position, there are two namely preverbal and post-verbal ones. In the preverbal position, so is followed by a verb. See example 11 below, where so is followed by well protected.

\section{(Example 11)}

"My Lord, it makes sense," said Wormtail, sounding thoroughly relieved now. "Laying hands on Harry Potter would be so difficult, he is so well protected - " (p.5)

"Yang Mulia, itu masuk akal," kata Wormtail, sekarang terdengar lega sekali.

"Menangkap Harry Potter akan sulit sekali, dia dilindungi amat ketat..." (4)

The translation of the so anaphora so well protected is literal, meaning that the passive form is translated into passive too, and so it becomes dilindungi amat ketat in Bahasa Indonesia. 
An in this case deep anaphora is adopted where the intended referent must e inferred from the source clause.

Besides pre-verbal construction, as shown I Example 11, post-verbal construction also exists with the construction of $\mathrm{V}+$ so.

(Example 12)

"Hope it's Angelina," said Fred as Harry, Ron, and Hermione sat down.

"So do I!" said Hermione breathlessly. "Well, we'll soon know!" (170)

"Mudah-mudahan Angelina," kata Fred ketika Harry, Ron, dan Hermione duduk.

"Aku juga berharap begitu!" kata Hermione menahan napas. "Yah, kita akan segera tahu!" (p.122)

The translation of So do I is Aku juga berharap begitu. Why the translator translated the phrase into such a sentence because he thought that the Hermione understood that Fred really hope that something good happens to Angelina.

(Example13)

He hadn't thought of that. How were the Weasleys going to pick him up? They didn't have a car anymore; the old Ford Anglia they had once owned was currently running wild in the Forbidden Forest at Hogwarts. But Mr. Weasley had borrowed a Ministry of Magic car last year; possibly he would do the same today?

"I think so," said Harry. (p.25)

Harry tidak memikirkannya. Bagaimana caranya keluarga Weasley akan menjemputnya? Mereka tak lagi punya mobil. Ford Anglia tua yang pernah mereka miliki sekarang berkeliaran di Hutan Terlarang di Hogwarts. Tetapi Mr Weasley meminjam mobil Kementerian Sihir tahun lalu, mungkin hari ini juga begitu?

"Kurasa begitu," kata Harry. (p.19)

The so anaphora of think so is semantically controlled, where in the construction above, the meaning is derived from the precious sentence. The translator also translate the construction literally, namely Kurasa begitu.

Deep anaphora in this construction can also be seen in example 13.

(Example 13)

They did it in groups today; Harry, Ron, and Hermione (the most conspicuous, since they were accompanied by Pigwidgeon and Crookshanks) went first; they leaned casually against the barrier, chatting unconcernedly, and slid sideways through it... and as they did so, platform nine and three-quarters materialized in front of them. (102)

Mereka melakukannya berkelompok hari ini. Harry, Ron, dan Hermione (yang paling mencolok, karena mereka ditemani Pigwidgeon dan Crookshanks), masuk paling dulu. Mereka bersandar ke palang rintangan, mengobrol santai, dan berhasil masuk... peron sembilan tiga perempat tiba-tiba muncul di hadapan mereka (p.75) 
From the translation of they did so into berhasil masuk, it seems that the translator really explicates the so anaphora into the intended meaning in the source language deriving from the semantic sense.

\section{(Example 14)}

"Well, you can enchant a building so it's impossible to plot on a map, can't you?"

"Er... if you say so," said Harry. (p.104)

"Yah, kau bisa menyihir bangunan supaya tak bisa tampak di peta, kan?"

"Er... kalau menurutmu begitu," kata Harry (p.76)

Deep anaphora is also shown in the example14, where the translator translates if you say so into kalau menurutmu begitu, derived from the previous sentence.

The next example shows that the anaphora construction is also used to give an opinion about what has been stated by the interlocutor.

(Example 14)

"How, then? Broomsticks?" Harry suggested, looking up at the starry sky.

"I don't think so... not from that far away..." (p.154)

"Kalau begitu naik apa? Sapu?" tanya Harry, memandang langit yang bertabur bintang.

"Kurasa juga tidak... tidak mungkin dari tempat sejauh itu..." (p.111)

In this example the translator also translates the so anaphora literally, but of course in the right form in bahasa Indonesia.

\section{Pronominal Event Reference}

Pronominal event references in this case are in the forms of that Is true, that was a big thing, the can't do that, that was a lie. The pronominal event references may show a wide types of reference to which that can be used to refer to. In example 15 - 16 that refers to a speech act and an expressed description, respectively (Weber, 1991 in Kehler and Ward, 2006).

(Example 15)

"That is true," said the second man, sounding amused. "A stroke of brilliance I would not have thought possible from you, Wormtail - though, if truth be told, you were not aware how useful she would be when you caught her, were you?"'(p.6)

"Itu betul," kata pria yang kedua, kedengarannya geli. "Itu tindakan brilian, tak pernah terpikir olehku kau bisa melakukannya, Wormtail... meskipun, kalau mau jujur, kau tidak sadar betapa bergunanya dia ketika kau menangkapnya, kan?" (p.5)

The translation is That is true which is as a speech act is Itu betul. In this case not shift happens. Because there is a similar intention between the English utterance and its intention in bahasa Indonesia. 
(Example 16)

"He'll be all right," said Mr. Weasley quietly as they marched off onto the moor. "Sometimes, when a person's memory's modified, it makes him a bit disorientated for a while... and that was a big thing they had to make him forget." (p.91)

"Dia akan baik-baik saja," kata Mr Weasley pelan sementara mereka berjalan ke tanah kosong. "Kadang-kadang, kalau memori orang dimodifikasi, untuk sementara dia jadi bingung selama beberapa waktu... apalagi yang harus dilupakannya hal besar. (p.67)

In this example, that was a big thing is translated into hal besar. In this form, the word that refers to description to convey, and there is omission of that was in the translation. But it will not change the meaning conveyed.

(Example 17)

Dumbledore sat down again and turned to talk to Mad-Eye Moody. There was a great scraping and banging as all the students got to their feet and swarmed toward the double doors into the entrance hall.

"They can't do that!" said George Weasley, who had not joined the crowd moving toward the door, but was standing up and glaring at Dumbledore. "We're seventeen in April, why can't we have a shot?'(p.107)

Dumbledore duduk lagi dan berpaling untuk berbicara kepada Mad-Eye Moody. Terdengar bunyi derit dan dentang ketika anak-anak bangkit dan beramai-ramai berjalan ke pintu ganda yang membuka ke Aula Depan.

"Tidak bisa begitu!" kata George Weasley, yang tidak bergabung dengan rombongan yang bergerak ke pintu, melainkan berdiri dan mendelik ke arah Dumbledore. "April nanti kami tujuh belas, kenapa kami tak boleh ikut?" (p.87)

The pronominal demonstrative that in 'They can't do that!' is deep anaphora in its type. As mentioned above, it is semantically controlled, meaning that the meaning of that is derived from the previous sentences. Concerning with the translation, "Tidak bisa begitu", there is no subject at all. But this form is still able to convey a complete meaning of the original.

\section{IV.CONCLUSION}

From the findings and the analysis above it can be stated that translating verb phrase ellipsis and event reference especially in the JK Rowling's' Harry Potter and the Goblet of Fire is not easy. It is due to the fact that before translating them, translators should derive meanings from the antecedents by taking into account of surface and deep anaphora, new and old information, salience, and the like. Despite such difficulties, the translations of ellipsis and reference in this novel are good enough. It can be proved from the findings that the translator is successful in conveying the content or the message of the expression into bahasa Indonesia with good readership and acceptability. 


\section{REFERENCES}

Bassnett, Susan. (2002). Translation Studies. London and New York: Routledge.

Bussman, Hadomon. (1998). Routledge Dictionary of Language and Linguistics. New York and London: Routledge.

Curse, Alan. (2006). A Glossary of Semantics and Pragmatics. Edinburgh: Edinburgh University Press.

Horn, Lawrence R. \& Ward, Gregory (Eds.). (2006). The Handbook of Pragmatics. Maiden: Blackwell Publishing.

Kehler, Andrew \& Ward, Gregory. (2006). "Constraints on Ellipsis and Event Reference”. In Lawrence \& Ward (Eds.). The Handbook of Pragmatics. (pp 383 - 402). Maiden: Blackwell Publishing.

Nida, Eugene, A. \& Taber, Charles, R. (1982). The Theory and Practice of Translation. Leiden: E. J. Brill.

Stranz, Phillip (Ed.). (2006). Encyclopedia of Linguistics. New York and Oxon: Fitzroy Dearorn.

Yule, George. (1996). Pragmatics. Oxford: Oxford University Press. 